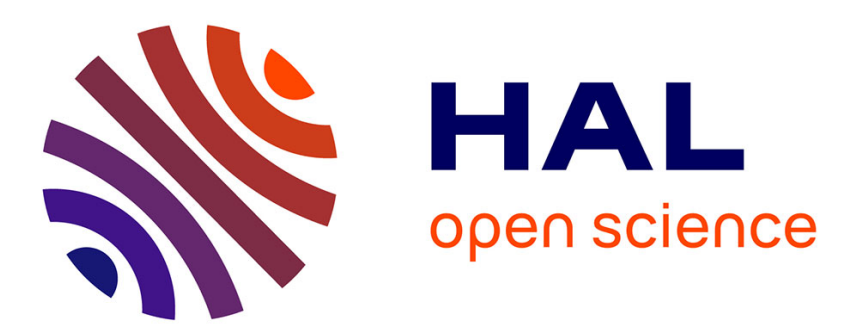

\title{
Controlled radical polymerization of alkyl acrylates and styrene using a half-sandwich molybdenum(III) complex containing diazadiene ligands
}

François Stoffelbach, David Haddleton, Rinaldo Poli

\section{- To cite this version:}

François Stoffelbach, David Haddleton, Rinaldo Poli. Controlled radical polymerization of alkyl acrylates and styrene using a half-sandwich molybdenum(III) complex containing diazadiene ligands. European Polymer Journal, 2003, 39 (11), pp.2099-2105. 10.1016/S0014-3057(03)00152-6 . hal-03282757

HAL Id: hal-03282757

https://hal.science/hal-03282757

Submitted on 19 Jul 2021

HAL is a multi-disciplinary open access archive for the deposit and dissemination of scientific research documents, whether they are published or not. The documents may come from teaching and research institutions in France or abroad, or from public or private research centers.
L'archive ouverte pluridisciplinaire HAL, est destinée au dépôt et à la diffusion de documents scientifiques de niveau recherche, publiés ou non, émanant des établissements d'enseignement et de recherche français ou étrangers, des laboratoires publics ou privés. 


\title{
Controlled Radical Polymerization of Alkyl Acrylates and Styrene Using a Half-Sandwich Molybdenum(III) complex containing Diazadiene Ligands
}

\author{
François Stoffelbach, ${ }^{a}$ David M. Haddleton ${ }^{b}$ and Rinaldo Poli*a
}

${ }^{a}$ Laboratoire de Synthèse et d'Electrosynthèse Organométalliques (LSEO UMR 5632), Université de Bourgogne, Faculté de Sciences "Gabriel”, 6 boulevard Gabriel, 21000 Dijon, France.

Department of Chemistry, University Of Warwick, Coventry, CV4 7AL, UK 44-2476523256,d.m.haddleton@warwick.ac.uk

Proofs to: Prof. Rinaldo Poli

Tel +33380396881

Fax +33380393720

E-mail: poli@u-bourgogne.fr

Keywords

Atom Transfer Radical Polymerization, Molybdenum, polyacrylate, polystyrene, block copolymer 
Abstract : The half-sandwich molybdenum(III) complex $\mathrm{CpMoCl}_{2}\left({ }^{\mathrm{i}} \operatorname{Pr}_{2}-\mathrm{dad}\right)\left({ }^{\mathrm{i}} \mathrm{Pr}_{2}\right.$-dad $={ }^{\mathrm{i}} \mathrm{Pr}-$ $\mathrm{N}=\mathrm{CH}-\mathrm{CH}=\mathrm{N}-{ }^{\mathrm{i}} \mathrm{Pr}$ ) proved to be an effective metal catalyst for the controlled radical polymerization of methyl acrylate, butyl acrylate, and styrene. In conjunction with an alkyl iodide [R-I : $\left.\mathrm{CH}_{3} \mathrm{CH}(\mathrm{COOEt}) \mathrm{I}\right]$ as an initiator and in the presence or absence of $\mathrm{Al}(\mathrm{O}-i-\mathrm{Pr})_{3}$ as a co-catalyst, the molybdenum-based system gave polymers with narrow molecular weight distributions. The in-situ addition of styrene to a macroinitiator of poly(methylacrylate) afforded an AB-type block copolymer.

\section{Introduction}

Controlled radical polymerization has become a heavily investigated area of research due to its high tolerance of polar functionalities and the ability to develop well defined macromolecular architectures. ${ }^{1-7}$ Transition metal mediated controlled radical polymerisation has attracted considerable attention with many different catalyst systems based on $\mathrm{Cu}(\mathrm{I}),{ }^{8-15}$ $\mathrm{Fe}(\mathrm{II}),{ }^{16-20} \mathrm{Ni}(\mathrm{II}, 0),{ }^{21-23} \mathrm{Ru}(\mathrm{II}),{ }^{24-27} \mathrm{Re}(\mathrm{V}),{ }^{28} \mathrm{Mo}(\mathrm{V}$ and $\mathrm{III}),{ }^{29-32} \mathrm{Pd}(0),{ }^{33} \mathrm{Co}(\mathrm{II}){ }^{34}$ and $\mathrm{Rh}(\mathrm{I})^{35,36}$ being studied. Our recent discovery that complexes $\mathrm{CpMoCl}_{2}\left(\mathrm{PMe}_{3}\right)_{2}$ and $\mathrm{CpMoCl}_{2}$ (dppe) are able to control the radical polymerization of styrene by two different mechanisms simultaneously, i.e., ATRP and SFRP, ${ }^{30}$ prompted us to extend our study to other half-sandwich Mo complexes with different ligands. Recently, we have reported the controlled radical polymerization of styrene with new $\mathrm{CpMoCl}_{2}\left(\mathrm{R}_{2}\right.$-dad) complexes $\left(\mathrm{R}_{2}\right.$-dad $=$ $\mathrm{RN}=\mathrm{CH}-\mathrm{CH}=\mathrm{NR}$ with $\mathrm{R}=\mathrm{Ph}, p-\mathrm{Tol}, 2,6-{ }^{\mathrm{i}} \mathrm{Pr}_{2} \mathrm{C}_{6} \mathrm{H}_{3}$ and ${ }^{\mathrm{i}} \mathrm{Pr}$ ) under typical SFRP (Stable Free Radical Polymerization) and ATRP (Atom Transfer Radical Polymerization) conditions. The SFRP polymerization occurs by using the Mo(III) complex in conjunction with 2,2'azobis(isobutyronitrile) (AIBN) as a conventional radical initiator (the dormant species being 
an alkylmolybdenum(IV)-terminated polymer chain), whereas the ATRP polymerization occurs by using the Mo(III) complex and 1-bromoethylbenzene as an initiator. ${ }^{32}$

In this paper, we present results demonstrating that $\mathrm{CpMoCl}_{2}\left(\mathrm{Pr}_{2}\right.$-diazadiene $)$ is an efficient catalyst for the controlled free radical polymerization of methyl acrylate, butyl acrylate, and styrene, in the presence or absence of a catalytic promoter. We demonstrated that an iodide initiator works better for acrylates like in copper-mediated ATRP ${ }^{37}$ and works well for styrene like in ruthenium- and rhenium-based ARTP. ${ }^{28,38}$ As an extension of this investigation, we present the polymerization of methyl acrylate followed by styrene to afford the respective block copolymer, representing the first report of a block co-polymer prepared with a molybdenum-based catalyst.

\section{Results and Discussion}

Homopolymerization of methyl acrylate. The polymerization of acrylate monomers under ATRP conditions with a molybdenum based catalyst complex has not been reported to date. Styrene has been reported to be polymerised by ATRP with Mo based systems but previous attempts to polymerise the acrylates via ATRP with complexes $\mathrm{CpMoCl}_{2} \mathrm{~L}_{2}\left(\mathrm{~L}=\mathrm{PMe}_{3}\right.$ or $\mathrm{L}_{2}$ $\left.=\eta^{4}-\mathrm{C}_{4} \mathrm{H}_{6}\right)$ was unsuccessful. ${ }^{30} \mathrm{~A}$ first attempt to carry out the ATRP of methyl acrylate using $\mathrm{CpMoCl}_{2}\left({ }^{\mathrm{i}} \mathrm{Pr}_{2}\right.$-diazadiene $) / \mathrm{BrEA}\left(\mathrm{BrEA}=\mathrm{CH}_{3} \mathrm{CH}(\mathrm{Br}) \mathrm{COOEt}\right)$ at $80{ }^{\circ} \mathrm{C}$ in toluene solution $(30 \% \mathrm{v} / \mathrm{v})$ yielded no polymer after 24 hours. A small conversion (about $2 \%)$ was observed for the same mixture at $100{ }^{\circ} \mathrm{C}$ after 24 hours. This prompted us to use an iodide based initiator, since faster ATRP processes have been observed for the $\mathrm{Cp} * \mathrm{RuCl}\left(\mathrm{PPh}_{3}\right)_{2} / \mathrm{Al}(\mathrm{O}-i$ $\mathrm{Pr})_{3} / \mathrm{RX}$ initiating system when using iodide initiators instead of the bromide analogues due to the relatively weak C-I bond. ${ }^{39}$ Using $\mathrm{CH}_{3} \mathrm{CH}(\mathrm{I}) \mathrm{COOEt}$ ) (IEA) as an initiator under the same conditions as described above yielded the results shown in Figure 1. The polymerization exhibited excellent linear correlation of the $\mathrm{M}_{\mathrm{n}}$ as a function of conversion and a decrease in 
PDI throughout the reaction, although the initiator efficiency (f) was low. ${ }^{40}$ The $f$ factor is calculated as the ratio between the theoretical slope and the slope of the least-squares fit of the experimental data for the Mn vs. conversion plot with the imposition of a zero intercept.

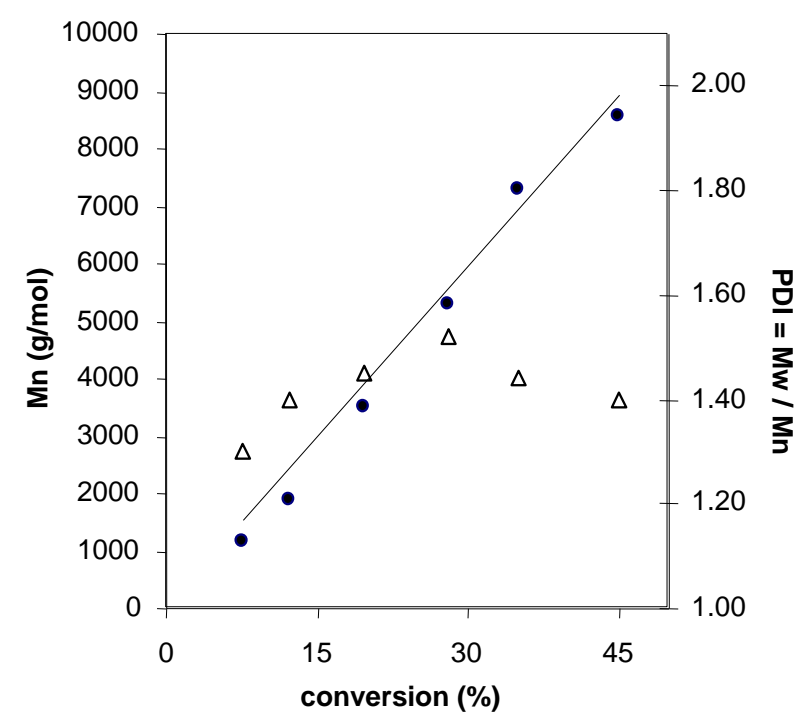

Figure 1. $\mathrm{M}_{\mathrm{n}}$ (black dots) and PDI (open triangles) vs. conversion for the polymerization of methyl acrylate using $\mathrm{CpMoCl}_{2}\left({ }^{\mathrm{i}} \mathrm{Pr}_{2}\right.$-diazadiene $) / \mathrm{IEA}(\mathrm{MA} / \mathrm{Mo} / \mathrm{IEA}=140 / 1 / 1)$ in toluene $(30 \% \mathrm{v} / \mathrm{v})$ at $100{ }^{\circ} \mathrm{C}$. The straight line is the least squares fit of the experimental data $(f=0.6)$.

The polymerisation follows first order kinetics as would be expected for a living polymerisation (see Figure 2). However, the apparent first order rate constant is low $\left(1.2 \times 10^{-6}\right.$ $\mathrm{s}^{-1}$ ) with six days being required to obtain $50 \%$ conversion. In an attempt to increase the polymerisation rate, we utilised the Lewis acid activator $\mathrm{Al}(\mathrm{O}-i-\mathrm{Pr})_{3}$, which is known to accelerate the ATRP for other systems. ${ }^{41-43}$ Indeed, the presence of $\mathrm{Al}(\mathrm{O}-i-\mathrm{Pr})_{3}$ had a dramatic effect on the polymerisation rate (see Figure 3), with $k_{\text {app }}$ increasing to $1.7 \times 10^{-5} \mathrm{~s}^{-1}$ for $\mathrm{Al} / \mathrm{Mo}=1$. 


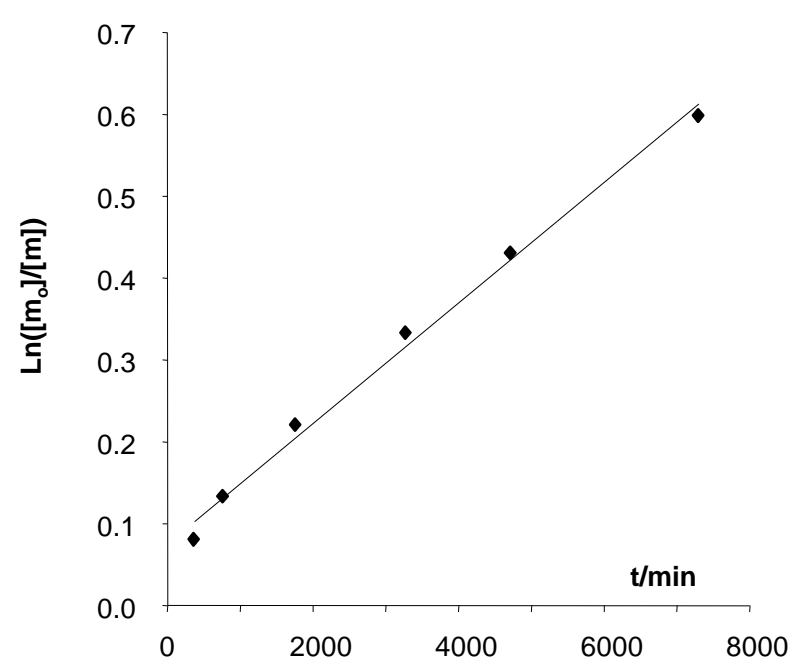

Figure 2. First order kinetic plot for the polymerisation of MA obtained in the presence of $\mathrm{CpMoCl}_{2}\left({ }^{\mathrm{i}} \mathrm{Pr}_{2}\right.$-diazadiene $) / \mathrm{IEA}\left(\mathrm{MA} / \mathrm{M}_{\mathrm{o}} / \mathrm{IEA}=140 / 1 / 1\right)$ in toluene solution $(30 \%$ $\mathrm{v} / \mathrm{v})$ at $100{ }^{\circ} \mathrm{C}$.

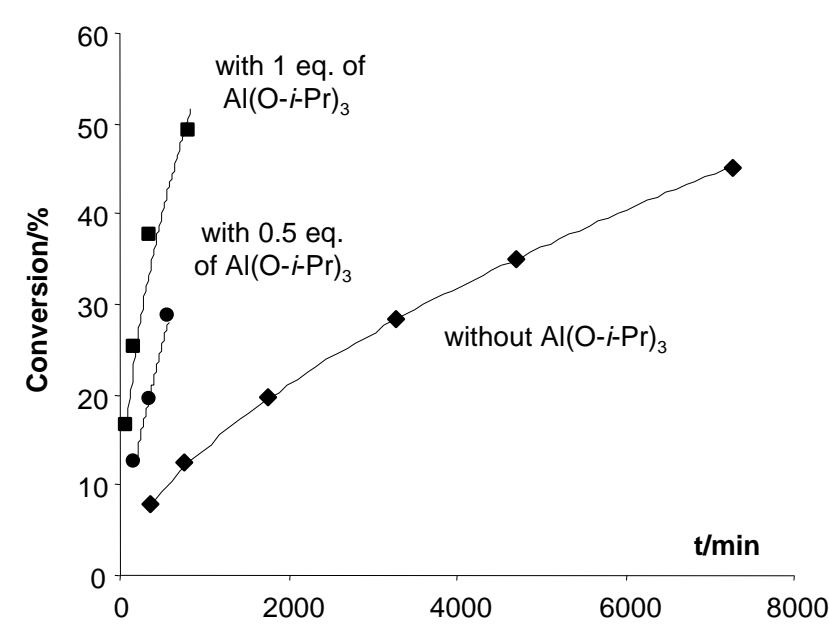

Figure 3. Polymerisation conversion vs. time for PMA in the presence of $\mathrm{CpMoCl}_{2}\left(\mathrm{Pr}_{2}-\right.$ diazadiene)/IEA in toluene solution $(30 \% \mathrm{v} / \mathrm{v})$ at $100{ }^{\circ} \mathrm{C}$ and variable amounts of $\mathrm{Al}(\mathrm{O}-i-\mathrm{Pr})_{3} . \quad[\mathrm{Ma}] /[\mathrm{IEA}] /[\mathrm{Mo}] /\left[\quad \mathrm{Al}(\mathrm{O}-i-\mathrm{Pr})_{3}\right] \quad=\quad 151 / 1 / 1 / 1 \quad(\mathbf{\bullet})$; $[\mathrm{Ma}] /[\mathrm{IEA}] /[\mathrm{Mo}] /\left[\mathrm{Al}(\mathrm{O}-i-\mathrm{Pr})_{3}\right]=171 / 1 / 1 / 0.5(\bullet) ;[\mathrm{Ma}] /[\mathrm{IEA}] /[\mathrm{Mo}]=140 / 1 / 1$ $(\diamond)$.

The polymerisation rate increased with the concentration of aluminum compound, as expected. Even under these reaction conditions, the $\mathrm{M}_{\mathrm{n}}$ increased linearly with conversion and the PDIs remain relatively low, indicating that the polymerisation remained controlled although still characterized by low $\mathrm{f}$ values. ${ }^{40}$ Results consistent with living-type polymerisation with fast initiation and little or no termination were obtained at a lower 
temperature $\left(80{ }^{\circ} \mathrm{C}\right.$, see Figure 4$)$. The PDIs obtained were narrower $\left(1.16<\mathrm{M}_{\mathrm{w}} / \mathrm{M}_{\mathrm{n}}<1.24\right)$ with a higher initiator efficiency. $50 \%$ conversion was reached at this temperature after only 24 hours.

The intervention of degenerative transfer processes has been recognized as a possibility during ATRP when using iodide initiators. ${ }^{44,45}$ In order to test for this possibility, we have carried out the following experiments. A polymerization of MA carried out in the presence of AIBN as a source or radicals, IEA and the aluminum co-catalyst but in the absence of the Mo complex $([\mathrm{MA}] / \mathrm{IEA} / \mathrm{Al} / \mathrm{AIBN}=170 / 1 / 1 / 0.5)$ at $80^{\circ} \mathrm{C}$ yielded $95 \%$ conversion in $85 \mathrm{~min}$ and a polymer with $\mathrm{Mn}=11262(\mathrm{PDI}=2.76), v s$. a theoretical $\mathrm{Mn}$ of 4600 . A similar experiment carried out in the absence of AIBN ([MA]/IEA/Al $=151 / 1 / 0.5)$ at $100^{\circ} \mathrm{C}$ gave $22.7 \%$ conversion in $762 \mathrm{~min}$ and the resulting polymer had $\mathrm{Mn}=26942(\mathrm{PDI}=1.76)$, vs. a theoretical Mn of 2981. Clearly, a degenerative transfer mechanism does not play a significant role for the control of this polymerization. However, it cannot be excluded that, under the much lower radical concentration conditions of the ATRP process, such degenerative transfer contributes to better control the chain growth and reduce the effective polymerization rate.
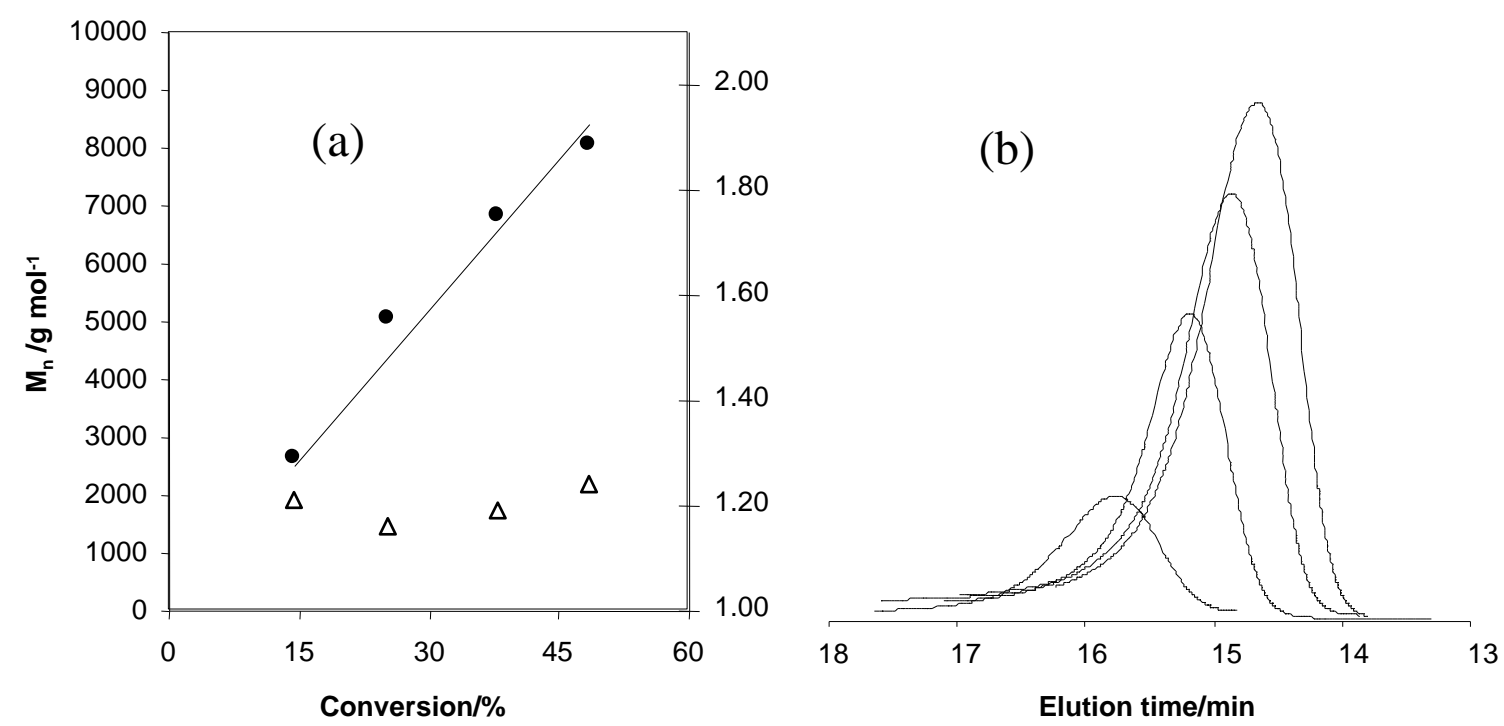
Figure 4. (a) $\mathrm{M}_{\mathrm{n}}$ (black dots) and PDI (open triangles) vs. conversion for PMA obtained in the presence of $\mathrm{CpMoCl}_{2}\left({ }^{\mathrm{i}} \mathrm{Pr}_{2}\right.$-diazadiene $) / \mathrm{Al}(\mathrm{O}-i$-Pr) $3 / \mathrm{IEA}(\mathrm{MA} / \mathrm{Mo} / \mathrm{Al} / \mathrm{IEA}=$ $171 / 1 / 1 / 1)$ in toluene solution $(30 \% \mathrm{v} / \mathrm{v})$ at $80{ }^{\circ} \mathrm{C}$. The straight line is the least squares fit of the experimental data $(f=0.85)(b)$ Size exclusion chromatograms of the polymer samples reported in part (a).

Given the dramatic increase in the polymerisation rate on the addition of $\mathrm{Al}\left(\mathrm{O}^{\mathrm{i}} \mathrm{Pr}\right)_{3}$, we also examined the effect of adding the $\mathrm{Al}\left(\mathrm{O}^{\mathrm{i}} \mathrm{Pr}\right)_{3}$ in a polymerisation initiated by a bromide initiator. The rate of polymerisation was substantially increased, even at $60{ }^{\circ} \mathrm{C}(51 \%$ conversion after $21 \mathrm{~h}$ ). Conversely, the molecular weight control was poor, with observed PDI's $>2$. This may result from the absence of degenerative exchange processes as compared with the iodide-initiated polymerization.

\section{Homopolymerization of n-butyl acrylate.}

Butyl acrylate (nBA) was polymerised using the $\mathrm{CpMoCl}_{2}\left(\mathrm{Pr}_{2}\right.$-dad)/IEA system in xylene $\left(120^{\circ} \mathrm{C}\right)$, toluene $\left(100{ }^{\circ} \mathrm{C}\right)$, and in the presence and absence of $\mathrm{Al}(\mathrm{O}-i-\mathrm{Pr})_{3}$ (see Figure 5). The rate of polymerisation increased with temperature and with catalytic promoter, as expected. The lowest PDIs $\left(1.30<\mathrm{M}_{\mathrm{w}} / \mathrm{M}_{\mathrm{n}}<1.46\right)$ were obtained at $100{ }^{\circ} \mathrm{C}$ in the presence of $\mathrm{Al}(\mathrm{O}-i-\mathrm{Pr})_{3}$ (Figure 6).

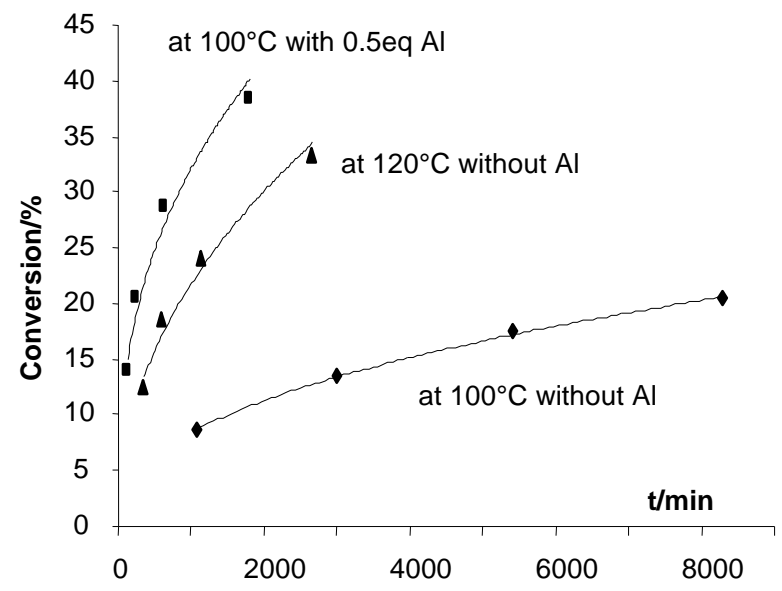


Figure 5. Polymerisation conversion vs. time for PBA in the presence of $\mathrm{CpMoCl}_{2}\left({ }^{\mathrm{i}} \mathrm{Pr}_{2}-\right.$ diazadiene) in solution $(30 \% \mathrm{v} / \mathrm{v}) .[\mathrm{Ba}] /[\mathrm{IEA}] /[\mathrm{Mo}] /\left[\mathrm{Al}(\mathrm{O}-i-\mathrm{Pr})_{3}\right]=155 / 1 / 1 / 0.5, \mathrm{~T}$ $=100^{\circ} \mathrm{C}(\boldsymbol{\bullet}) ;[\mathrm{Ba}] /[\mathrm{IEA}] /[\mathrm{Mo}] /\left[\mathrm{Al}(\mathrm{O}-i-\mathrm{Pr})_{3}\right]=150 / 1 / 1 / 0, \quad \mathrm{~T}=120^{\circ} \mathrm{C}(\bullet) ;$ $[\mathrm{Ba}] /[\mathrm{IEA}] /[\mathrm{Mo}] /\left[\mathrm{Al}(\mathrm{O}-i-\mathrm{Pr})_{3}\right]=155 / 1 / 1 / 0, \mathrm{~T}=100^{\circ} \mathrm{C}(\bullet)$.

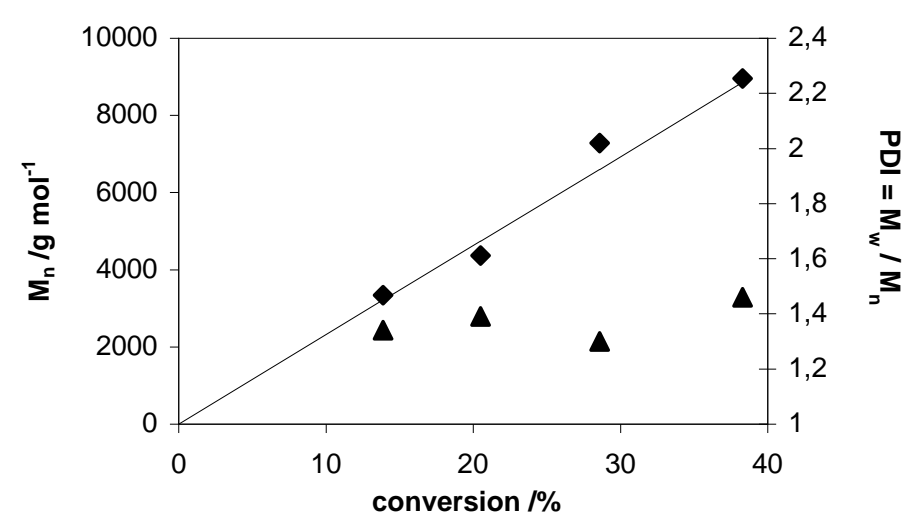

Figure 6. $\mathrm{M}_{\mathrm{n}}$ (diamonds) and PDI (triangles) vs. conversion for PBA obtained in the presence of $\mathrm{CpMoCl}_{2}\left(\mathrm{Pr}_{2}\right.$-diazadiene $) / \mathrm{Al}(\mathrm{O}-i \text {-Pr })_{3} / \mathrm{IEA}(\mathrm{BA} / \mathrm{Mo} / \mathrm{Al} / \mathrm{IEA}=155 / 1 / 0.5 / 1)$ in toluene solution $(30 \% \mathrm{v} / \mathrm{v})$ at $100^{\circ} \mathrm{C}$. The straight line is the least squares fit of the experimental data $(\mathrm{f}=0.85)$.

It is interesting to observe that the initiator efficiency is greater in the absence of the $\mathrm{Al}(\mathrm{O}-i-\mathrm{Pr})_{3}$ for this reaction, whereas the opposite trend has been observed in another case. ${ }^{43}$ The collective results shown so far demonstrate that the $\mathrm{CpMoCl}_{2}\left({ }^{\mathrm{i}} \mathrm{Pr}_{2}\right.$-diazadiene $) / \mathrm{IEA} / \mathrm{Al}(\mathrm{O}-$ $i$-Pr) $)_{3}$ initiating system is effective for the controlled/living radical polymerisation of acrylates with different alkyl groups.

\section{Homopolymerization of styrene.}

We have recently shown that styrene can be polymerised by ATRP in bulk at $90{ }^{\circ} \mathrm{C}$ using $\mathrm{CpMoCl}_{2}\left({ }^{\mathrm{i}} \mathrm{Pr}_{2}\right.$-diazadiene) and 1-bromoethylbenzene (BEB) as an initiator. ${ }^{32}$ In order to know if a macroinitiator of poly(methyl-acrylate)- $\mathrm{CH}_{2} \mathrm{CH}(\mathrm{COOMe}) \mathrm{I}$ would be able to initiate the styrene polymerisation and yield a block copolymer, we carried out a polymerisation of styrene with the $\mathrm{CpMoCl}_{2}\left({ }^{\mathrm{i}} \mathrm{Pr}_{2}\right.$-dad $) / \mathrm{IEA} / \mathrm{Al}(\mathrm{O}-i-\mathrm{Pr})_{3}$ initiating system in solution at $90{ }^{\circ} \mathrm{C}$. 
The results, shown in Figure 7, demonstrate that the polymerisation seems to be better controlled under these conditions relative to those previously reported (greater polymerisation rate and lower PDIs).
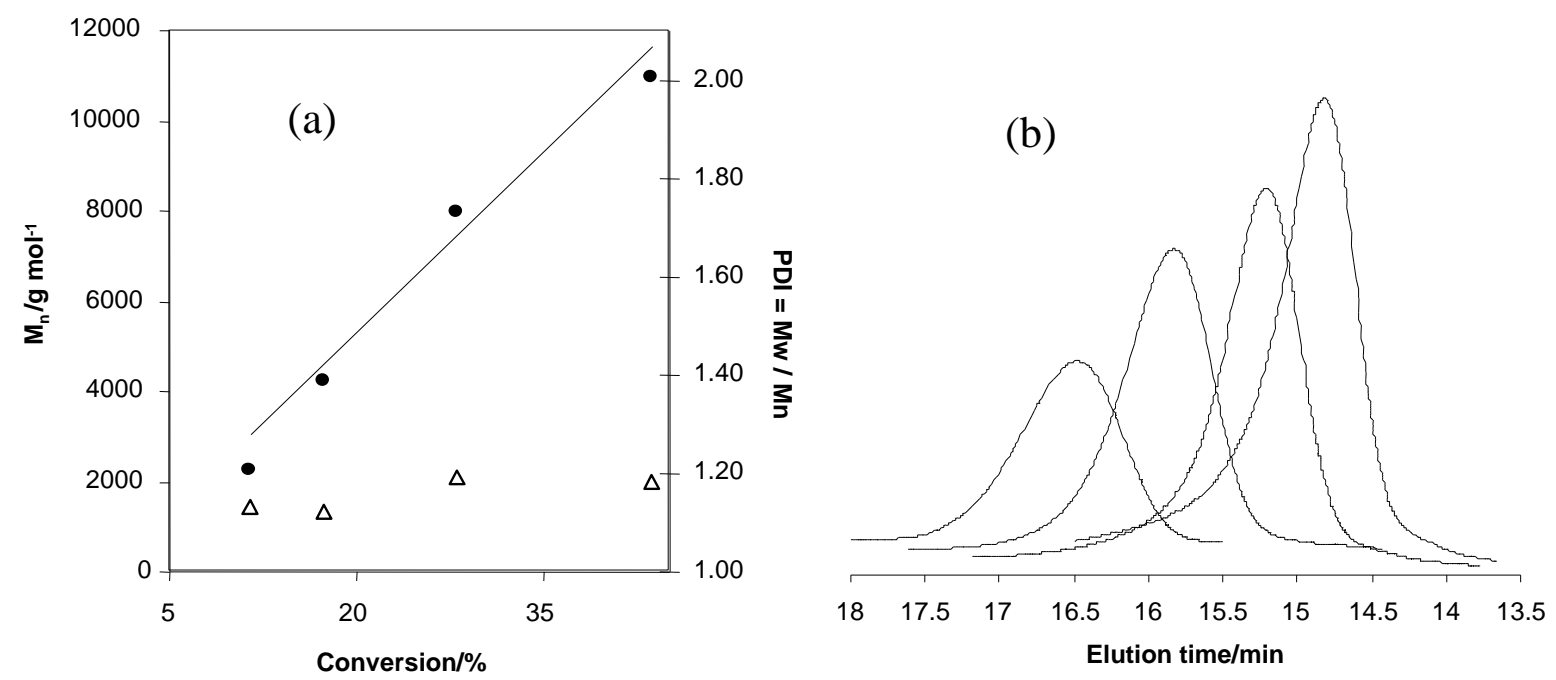

Figure 7. (a) $\mathrm{M}_{\mathrm{n}}$ (black circles) and PDI (open triangles) vs. conversion for PS obtained in the presence of $\mathrm{CpMoCl}_{2}\left({ }^{\mathrm{i}} \mathrm{Pr}_{2}\right.$-diazadiene $) / \mathrm{Al}(\mathrm{O}-i \text {-Pr })_{3} / \mathrm{IEA}(\mathrm{S} / \mathrm{Mo} / \mathrm{Al} / \mathrm{IEA}=$ $141 / 1 / 1 / 1)$ in toluene solution $(30 \% \mathrm{v} / \mathrm{v})$ at $90{ }^{\circ} \mathrm{C}$. The straight line is the least squares fit of the experimental data $(f=0.55)$. (b) Size exclusion chromatograms of the polymer samples reported in part (a).

As for the MA polymerisation described above, we considered it interesting to examine the effect of $\mathrm{Al}(\mathrm{O}-i-\mathrm{Pr})_{3}$ on a polymerisation initiated by a bromide initiator. As for that case, the $\mathrm{M}_{\mathrm{n}}$ increased linearly with the conversion with $\mathrm{f}$ close to unity, but the PDIs were very high $(>2)$.

\section{Block Copolymerization}

On the basis of the living homopolymerisations of both methyl acrylate and styrene with an acrylate initiator, a sequential block co-polymerisation of MA and styrene was examined with the molybdenum-based catalyst. MA was first polymerised with $\mathrm{CpMoCl}_{2}\left({ }^{\mathrm{i}} \mathrm{Pr}_{2}\right.$-dad)/IEA coupled with $\mathrm{Al}(\mathrm{O}-i-\mathrm{Pr})_{3}$ at $80^{\circ} \mathrm{C}$ in toluene. After $31 \%$ consumption of MA, the residual 
monomer and the toluene solvent were removed by evaporation $\left(\mathrm{a}{ }^{1} \mathrm{H}\right.$ NMR spectrum of this mixture showed the absence of residual MA) and a fresh solution of styrene in toluene was added to the poly(MA). As shown in Figure 8, the molecular weight distribution shifted to higher molecular weights while retaining a relatively narrow molecular weight distribution. These results show that each step of the sequential polymerisation is well controlled and virtually free from chain transfers and terminations to give homopolymers.

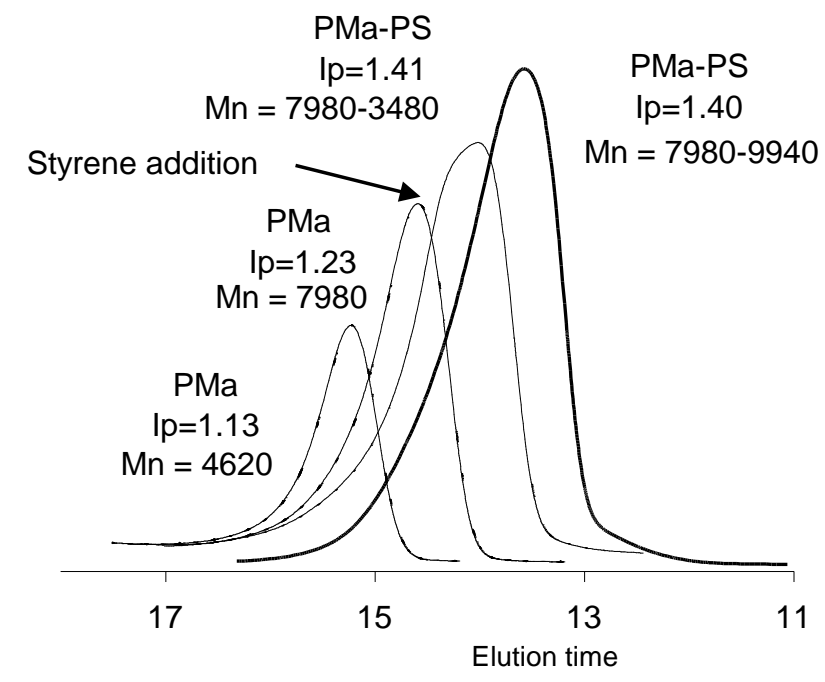

Figure 8. Size-exclusion chromatograms of the polymers obtained during the block polymerisation of methyl acrylate and styrene in the presence of $\mathrm{CpMoCl}_{2}\left({ }^{\mathrm{i}} \mathrm{Pr}_{2}-\right.$ diazadiene $) / \mathrm{Al}(\mathrm{O}-i \text { - } \mathrm{Pr})_{3} / \mathrm{IEA}(\mathrm{Ma} / \mathrm{Mo} / \mathrm{Al} / \mathrm{IEA}=174 / 1 / 1 / 1)$ in toluene solution $(30 \% \mathrm{v} / \mathrm{v})$ at $80^{\circ} \mathrm{C}$ and 128 equivalent of styrene (addition).

Figure 9 shows ${ }^{1} \mathrm{H}$ NMR spectra of the PMA- $b$-PS obtained, showing signals of the styrene repeat units and those of the MA units. Furthermore, the two small absorptions $a$ and $b$ at $\delta 4.16$ and 5.00, respectively, correspond to the ethyl $\mathrm{CH}_{2}$ group ${ }^{22}$ contained in the initiator at the MA chain, and to the terminal proton adjacent to the iodine atom at $\omega$-end. ${ }^{28,46}$ No vinyl groups are visible on this spectrum. The $\mathrm{M}_{\mathrm{n}}$ calculated from the peak intensity ratios c/a and d/a were 8280 and 9260, respectively, in close agreement with those obtained by sizeexclusion chromatography $\left[\mathrm{M}_{\mathrm{n}}(\mathrm{SEC})=7980\right.$ and 9940]. 


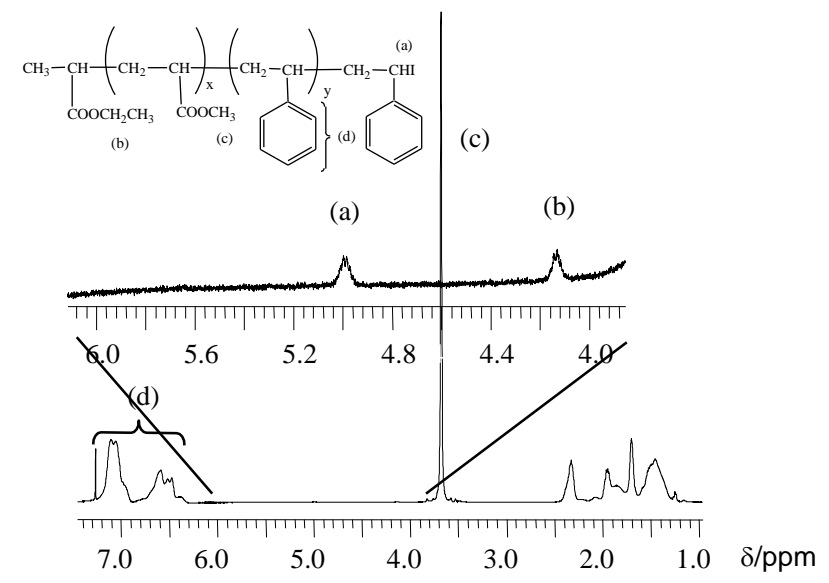

Figure 9. ${ }^{1} \mathrm{H}-\mathrm{NMR}$ spectrum of the PMA- $b$-PS sample with $\mathrm{Mn}=7980-9940$ shown in Figure 8.

\section{Conclusion}

The $\mathrm{CpMoCl}_{2}\left({ }^{\mathrm{i}} \mathrm{Pr}_{2}\right.$-dad)/IEA/Al$(\mathrm{O}-i-\mathrm{Pr})_{3}$ initiating system is capable of controlling the radical polymerisation of methyl and butyl acrylates and styrene. AB-type block copolymers of MA and styrene have been obtained by the ternary initiating systems. Furthermore, the $\mathrm{Al}(\mathrm{O}-i-\mathrm{Pr})_{3}$ compound plays a role as co-catalyst also in combination with this family of organometallic Mo complexes.

\section{Experimental Section}

General remarks. All reactions were carried out under an atmosphere of dry and oxygen-free argon using standard Schlenk techniques. Styrene was washed with an aqueous $\mathrm{NaOH}$ solution (10\%), followed by water, then dried over $\mathrm{MgSO}_{4}$ and finally distilled at $25^{\circ} \mathrm{C}$ under reduced pressure. Methyl and butyl acrylate were passed through an alumina column and then distilled under argon. Toluene and xylene were purified by distillation under argon after drying over sodium benzophenone ketyl. (1-Bromoethyl)benzene and 2- 
bromopropionate were purchased from Aldrich Chemical Co and degassed before use. $\mathrm{Al}(\mathrm{O}-$ $i$-Pr) $)_{3}$ (Aldrich) was used as received and handled in a glovebox under dry and oxygen-free argon. Compounds $\mathrm{CpMoCl}_{2}\left({ }^{\mathrm{i}} \mathrm{Pr}_{2} \text {-dad }\right)^{32}$ and $\mathrm{CH}_{3} \mathrm{CH}(\mathrm{I}) \mathrm{COOEt}$ (IEA) ${ }^{47}$ were obtained according to previously described synthetic procedures.

Polymerization Procedures. All ATRP polymerisation reactions were conducted following the same experimental procedure. A typical procedure is described as a representative example. $\mathrm{CpMoCl}_{2}\left(\mathrm{Pr}_{2}\right.$-dad) and $\mathrm{Al}(\mathrm{O}-i \text {-Pr })_{3}$ were added to a $25 \mathrm{~mL}$ Schlenk tube equipped with a stirring bar. Styrene, toluene and 2-iodopropionate were added to the reaction flask by a syringe after a 20 min Ar purge. The Schlenk tube was immersed in an oil bath heated at $90^{\circ} \mathrm{C}$. Aliquots were withdrawn periodically for monitoring.

Measurements. The MWD, $\mathrm{M}_{n}$ and $\mathrm{M}_{\mathrm{w}} / \mathrm{M}_{\mathrm{n}}$ of the polymers were measured by sizeexclusion chromatography (SEC) using THF as eluent $(1 \mathrm{~mL} / \mathrm{min})$ at room temperature on two polystyrene gel columns (B Jordi) equipped with a refractive index detector. The columns were calibrated against standard polystyrene and PMMA (for PMA and PBA) (Polymer Laboratories). The $\mathrm{M}_{\mathrm{n}}$ of PMA and PBA were corrected by using the Mark-Houwink coefficients of ref. $[48,49] .{ }^{1} \mathrm{H}$ NMR spectra were recorded in $\mathrm{CDCl}_{3}$ at $25^{\circ} \mathrm{C}$ on a Brucker $500 \mathrm{MHz}$ spectrometer. The peaks positions are reported with positive shifts in ppm downfield of TMS, as calculated from residual solvent peaks.

Acknowledgements. We are grateful to the CNRS for support of this work through the programme "Catalyse et Catalyseurs pour l'Industrie et l'Environnement" and for a Ph.D. fellowship (BDI) to FS. We thank the Conseil Régional de Bourgogne for co-sponsoring FS's fellowship and for the funds used to purchase the SEC instrument. Part of this work was carried out by FS in the laboratory of DMH with support from COST D17 (short mission) and the Marie Curie Supramolecular and Macromolecular Training Site programme (MCFH2001-00397). 


\section{Supporting Information}

Tables of experimental and theoretical $\mathrm{M}_{\mathrm{n}}$ and PDI as a function of conversion for all ATRP processes (3 pages).

\section{References}

(1) Hawker, C. J.; Bosman, A. W.; Harth, E. Chemical Reviews (Washington, D. C.) 2001, 101, 36613688.

(2) Benoit, D.; Chaplinski, V.; Braslau, R.; Hawker, C. J. J. Am. Chem. Soc. 1999, 121, 3904-3920.

(3) Chiefari, J.; Chong, Y. K. B.; Ercole, F.; Krstina, J.; Jeffery, J.; Le, T. P. T.; Mayadunne, R. T. A.; Meijs, G. F.; Moad, C. L.; Moad, G.; Rizzardo, E.; Thang, S. H. Macromolecules 1998, 31, 55595562 .

(4) Matyjaszewski, K., Ed. Controlled Radical Polymerization; American Chemical Society: Washington DC, 1998.

(5) Patten, T. E.; Matyjaszewski, K. Acc. Chem. Res. 1999, 32, 895-903.

(6) Matyjaszewski, K.; Xia, J. H. Chem. Rev. 2001, 101, 2921-2990.

(7) Kamigaito, M.; Ando, T.; Sawamoto, M. Chem. Rev. 2001, 101, 3689-3745.

(8) Wang, J.-S.; Matyjaszewski, K. Macromolecules 1995, 28, 7901-7910.

(9) Wang, J.-S.; Matyjaszewski, K. J. Am. Chem. Soc. 1995, 117, 5614-5615.

(10) Patten, T. E.; Xia, J.; Abernathy, T.; Matyjaszewski, K. Science 1996, 272, 866-868.

(11) Percec, V.; Barboiu, B. Macromolecules 1995, 28, 7970-7972.

(12) Percec, V.; Barboiu, B.; Kim, J.-H. J. Am. Chem. Soc. 1998, 120, 305-316.

(13) Haddleton, D. M.; Jasieczek, C. B.; Hannon, M. J.; Shooter, A. J. Macromolecules 1997, 30, 21902193.

(14) Haddleton, D. M.; Crossman, M. C.; Dana, B. H.; Duncalf, D. J.; Heming, A. M.; Kukulj, D.; Shooter, A. J. Macromolecules 1999, 32, 2110-2119.

(15) Bes, L.; Huan, K.; Khoshdel, E.; Lowe, M.; McConville, C.; Haddleton, D. Eur. Polym. J. 2003, 39 , 5-13.

(16) Matyjaszewski, K.; Wei, M.; Xia, J.; McDermott, N. E. Macromolecules 1997, 30, 8161-8164.

(17) Ando, T.; Kamigaito, M.; Sawamoto, M. Macromolecules 1997, 30, 4507-4510.

(18) Kotani, Y.; Kamigaito, M.; Sawamoto, M. Macromolecules 2000, 33, 3543-3549.

(19) Louie, J.; Grubbs, R. H. Chem. Commun. 2000, 1479-1480.

(20) Gibson, V. C.; O'Reilly, R. K.; Reed, W.; Wass, D. F.; White, A. J. P.; Williams, D. J. Chem. Commun. 2002, 1850-1851.

(21) Granel, C.; Dubois, P.; Jerome, R.; Teyssie, P. Macromolecules 1996, 29, 8576-8582.

(22) Uegaki, H.; Kotani, Y.; Kamigaito, M.; Sawamoto, M. Macromolecules 1997, 30, 2249-2253.

(23) Uegaki, H.; Kotani, Y.; Kamigaito, M.; Sawamoto, M. Macromolecules 1998, 31, 6756-6761.

(24) Kato, M.; Kamigaito, M.; Sawamoto, M.; Higashimura, T. Macromolecules 1995, 28, 1721-1723.

(25) Ando, T.; Kato, M.; Kamigaito, M.; Sawamoto, M. Macromolecules 1996, 29, 1070-1072.

(26) Ando, T.; Kamigaito, M.; Sawamoto, M. Tetrahedron 1997, 53, 15445-15457.

(27) Nishikawa, T.; Ando, T.; Kamigaito, M.; Sawamoto, M. Macromolecules 1997, 30, 2244-2248.

(28) Kotani, Y.; Kamigaito, M.; Sawamoto, M. Macromolecules 1999, 32, 2420-2424.

(29) Brandts, J. A. M.; van de Geijn, P.; van Faassen, E. E.; Boersma, J.; van Koten, G. J. Organometal. Chem. 1999, 584, 246-253.

(30) Le Grognec, E.; Claverie, J.; Poli, R. J. Am. Chem. Soc. 2001, 123, 9513-9524.

(31) Stoffelbach, F.; Claverie, J.; Poli, R. C. R. Acad. Sci. Paris C 2002, 5, 37-42.

(32) Stoffelbach, F.; Poli, R.; Richard, P. J. Organometal. Chem. 2002, 663, 269-276.

(33) Lecomte, P.; Draiper, I.; Dubois, P.; Teyssié, P.; Jérôme, R. Macromolecules 1997, 30, 7631-7633.

(34) Christie, D.; Claverie, J.; Kanagasabapathy, S.; BASF, 1999.

(35) Percec, V.; Barboiu, B.; Neumann, A.; Ronda, J. C.; Zhao, M. Macromolecules 1996, 29, 3665-3668.

(36) Moineau, G.; Granel, C.; Dubois, P.; Jérôme, R.; Teyssié, P. Macromolecules 1998, 31, 542-544. 
(37) Davis, K.; O'Malley, J.; Paik, H.-J.; Matyjaszewski, K. Polymer Preprints (American Chemical Society, Division of Polymer Chemistry) 1997, 38, 687-688.

(38) Kotani, Y.; Kamigaito, M.; Sawamoto, M. Macromolecules 2000, 33, 6746-6751.

(39) Watanabe, Y.; Ando, T.; Kamigaito, M.; Sawamoto, M. Macromolecules 2001, 34, 4370-4374.

(40) The reason for the low $\mathrm{f}$ value in this and all other radical polymerisations reported in the current paper is being investigated and will be discussed in another forthcoming contribution..

(41) Kato, M.; Kamigaito, M.; Sawamoto, M.; Higashimura, T. Macromolecules 1995, 28, 1721-1723.

(42) Guo, J.; Han, Z.; Wu, P. Journal of Molecular Catalysis A: Chemical 2000, 159, 77-83.

(43) Fuji, Y.; Ando, T.; Kamigaito, M.; Sawamoto, M. Macromolecules 2002, 35, 2949-2954.

(44) Matyjaszewski, K.; Gaynor, S.; Wang, J. S. Macromolecules 1995, 28, 2093-2095.

(45) Gaynor, S. G.; Wang, J. S.; Matyjaszewski, K. Macromolecules 1995, 28, 8051-8056.

(46) Egorov, A. M.; Anisimov, A. V. J. Organomet. Chem. 1995, 495, 131-134.

(47) Curran, D. P.; Bosch, E.; Kaplan, J.; Newcomb, M. J. Org. Chem. 1989, 54, 1826-1831.

(48) R.A. Hutchinson, D.A. Paquet Jr., J.H. McMinn, S. Beuermann, R.E. Fuller, C. Jackson, DECHEMA Monogr., 1995, 131, 467-491.

(49) S. Beuermann, private communications. 